\title{
TTR
}

Traduction, terminologie, rédaction

\section{Manuela Perteghella and Eugenia Loffredo, eds. Translation and Creativity. Perspectives on Creative Writing and Translation Studies. London, Continuum, 2007, 197 p.}

\section{Corrado Federici}

Volume 21, numéro 2, 2e semestre 2008

La formation en traduction : pédagogie, docimologie et technologie II Translator Training: Pedagogy, Evaluation, and Technologies II

URI : https://id.erudit.org/iderudit/037500ar

DOI : https://doi.org/10.7202/037500ar

Aller au sommaire du numéro

Éditeur(s)

Association canadienne de traductologie

ISSN

0835-8443 (imprimé)

1708-2188 (numérique)

Découvrir la revue

Citer ce compte rendu

Federici, C. (2008). Compte rendu de [Manuela Perteghella and Eugenia Loffredo, eds. Translation and Creativity. Perspectives on Creative Writing and Translation Studies. London, Continuum, 2007, 197 p.] TTR, 21(2), 266-269. https://doi.org/10.7202/037500ar

Tous droits réservés @ $@$ TTR: traduction, terminologie, rédaction — Les auteurs, 2009
Ce document est protégé par la loi sur le droit d'auteur. L'utilisation des services d'Érudit (y compris la reproduction) est assujettie à sa politique d'utilisation que vous pouvez consulter en ligne.

https://apropos.erudit.org/fr/usagers/politique-dutilisation/ 
Cependant, nous saluons les ponts que jettent Hokenson et Munson entre le rôle de traducteur et celui d'écrivain bilingue. En effet, en mettant l'accent sur les gains qu'offre le texte traduit, et surtout en insistant sur les similitudes plutôt que les dissemblances, elles invitent les traductologues à envisager le produit traduit sous un angle nouveau, et à voir le lien qui unit les différentes versions comme dialogique. L'élargissement de telles réflexions sur la littérature bilingue devrait d'autre part permettre aux traducteurs de gagner en assurance, en autonomie et pourrait contribuer à revaloriser leur statut.

\section{Laurence Jay-Rayon Université de MontréAL}

\section{Manuela Perteghella and Eugenia Loffredo, eds. Translation and Creativity. Perspectives on Creative Writing and Translation Studies. London, Continuum, 2007, 197 p.}

The editors indicate that the aim of the book is to discuss the links between translation and creative writing, which is largely a response to the naive view of translation as a mechanical activity that, one day, will be performed entirely by computers. As Ann Pattison, one of the contributing authors contends, "For too long now, translation has been perceived by many as a form of writing by proxy, an activity that people engage in as a kind of second best because they cannot find words of their own" (p. 92). The essays in the present volume provide compelling evidence that literary translation is, indeed, a creative activity.

After a substantial 16-page Introduction, which frames the contributions very effectively, Perteghella and Loffredo arrange eleven essays into four parts, the titles of which identify the key issues addressed. The first part, "Creating trends: exploring new frontiers," includes views on self-translation from Paschalis Nikolaou who offers instances of creativity in translation by entering into the "nebulous juncture of creative writing and literary translation” (p. 20). Nikolaou examines what she calls the "black box" of literary consciousness for the purpose of locating "traces of translators' voices and circumstances in their 
re-voicing of other authors" (p. 31). Clive Scott also addresses the question of the space occupied by both the reading of the source text and by the translator's intended target text: both seen as fictionalizations. He states: "It is not a text we translate, so much as a reading of a text" (p. 34). Referring to Roland Barthes' distinction between the readerly text and the writerly text, Scott argues that, "translation endeavours to transform the ST as 'lisible' into the TT as 'scriptible"' (p. 35). Jean Boase-Beier sees modern critical theory as an aid to creativity in both the reading and the translation of the source text. She takes up the question of the translator's creativity within the constraints inherent in the original texts by inquiring into how interpretations of texts are produced. Her contention is that familiarity with critical theory allows us to approach the task of translation in new ways.

Part Two, "Translation methodologies," includes Francis R. Jones' research into the processes of poetry translation. Given that there has been limited investigation into what poetry translators actually do, Jones considers the effectiveness of think-aloud studies that looked at the translation of classical Chinese verse into English, studies that "have generated valuable data about how trainee translators and non-translator poets actually translate poetry" (p. 60). Christiana Lambrinidis' work contributes to the development of a new methodology of translation practices in Greece. As co-founder of an experimental feminist publication series, she intends to fill the void created by a "lack of women's writing translated into Greek" (p. 79), through which women translators "could voice the realities of their own lives away from the vocal stereotypes Greek society enforces upon women as spoiled speech acts" (p. 80). Ann Pattison's chapter proposes training translators by teaching them to write as well as translate. Her proposal is a writing workshop in which the literary devices of canonical authors are studied, arguing that such workshops empower translators, "to see themselves as writers [and] should contribute to a redefinition of the status and role of the professional translator as a writer per se" (p. 91).

Part Three, "Case studies: translators as creative writers," takes up the notion of the writing spectrum and provides convincing demonstrations of creativity in translation. Xavier 
Lin probes the difference between poetic language and ordinary language as it pertains to Chinese poetry, where that difference is not at issue. He wants to know, "how creativity can function to recreate the aesthetic gestalt of the translated poem" (p. 103). In her essay, Manuela Perteghella examines the translation of Shakespeare's The Tempest by playwright Eduardo De Filippo, who sets the play in seventeenth-century Naples, thereby positioning the play within the tradition of Italian regional and popular theatre. She argues persuasively that poeticizing includes, "the use of certain imagery, poetry, stylistic devices, possibly even absent from the source text, which are usually taken from the target text culture repertoire and from the translator's own self as a writer" (p. 122).

In "Textuality and experiment," Part Four, we find Judy Kendall's study of the challenge posed by Japanese orthography. Her argument is the following: "If a given orthography participates in the meaning of a text then the conventional approach to translation of separating the meaning from the form, is no longer possible" (p. 130). To illustrate, she examines an English translation of Eiko Miyaji's Suiko/The Water Jar, suggesting that "[o]ne creative option for a translator is to work with concrete poetry techniques" (p. 133). Equally interesting is Chantal Wright's work on The Secret Report on the Poet Goethe, a novel written in German. She maintains that, "[p]erforming the translation is an opportunity to show the reader that translation is not a mechanical, objective task which results in a definitive, faithful translation but a subjective, manipulative process which results in one (or several) of many possible outcomes" (p. 147). Her performance consists of producing what she refers to as a "translation triptych" of passages from Goethe's Faust: a literal rendering, a translation for children, and a pop translation. The volume concludes with Eugenia Loffredo's trangeneric translation of Mère la mort by Jeanne Hyvrard, an author associated with écriture féminine. Since, as she tells us, "Hyvrard's language can be compared to a $[\ldots]$ singing voice that cannot be simply read but asks to be listened to" (p. 160), the translator has chosen the litany form because it is designed to enhance the rhythm and the sound of the singing voice. 
To conclude, Loffredo's remark, that "academic institutions are beginning to acknowledge that there is a role for creative writing in translators' education and professional development" (p. 93), may appear to be overly optimistic. Nevertheless, Translation and Creativity is an important publication that adds to the increasing research on the nature and value of literary translation and of those who perform this task.

Corrado Federici Brock UNIVERSITY 